\title{
Integration of Information and Communication Technologies Competencies in Business Education in Colleges of Education in the South East of Nigeria
}

\author{
Abiara Ijeoma Pamela \\ Department of Business Education \\ Ebonyi State College of Education, Ikwo \\ Ebonyi State, Nigeria \\ Dr. Chioma Vivienne Nwokoro, PhD \\ Department of Sociology \\ Eastern Palm University,Ogboko \\ Imo state, Nigeria \\ Dr. Felix Onwubuariri Chima, PhD \\ Prairie View A\&M University \\ Department of Social Work Education \\ United States of America
}

\begin{abstract}
The study sought to evaluate the Information and Communication Technologies (ICT) competencies required by Business Education lecturers in Colleges of Education in the South East of Nigeria. The population of the study comprised of 53 lecturers in the five selected Colleges of Education in the South East zone of Nigeria. The instrument for data collection was a structured questionnaire. The data collected were analysed using mean and standard deviation for research questions while the hypotheses were tested at 0.05 level of significance using t-test. The findings of the study showed that Business Education lecturers highly require ICT competencies like Microsoft word, internet, power point, spreadsheet and Database amongst others. The study also revealed that the knowledge of these ICT competencies is highly required for effective teaching of Business Education as a subject in Colleges of Education. The study thus recommends that lecturers should be encouraged to go for in service training to enable self-paced learning through e-leaning as well as by fostering a live contact between teachers and learners through e-mail, chalk session, web based learning including the use of internet.
\end{abstract}

Keywords: ICT, Business Education, Web based learning, Lecturers, Competencies

\section{Introduction}

Business Education is a skill oriented course. It gives individuals the skills to hire, learn and work as productive citizens in a global society. The economic down turn have great impact on the graduates of Business Education but it is likely to have a severe impact on these graduates who are not skilled in their area of study. Thus, according to Igbokwe (2012) Business Education is that aspect of the total educational programme that provides the knowledgeable skills, understanding and attitudes needed to perform in the business world as producers or consumers of goods and services that business offers. Igbokwe(2012) opined that the philosophy of Nigeria's education is based on the Nigeria National Objectives of particular interest to Business Education which includes the training of the mind in the understanding of the world around; the acquisition of appropriate skills, abilities and competences both mental and physical as equipment for individual to live in and contribute to the development of his society (FGN, 2004). Based on these, it is the function of the curriculum in tertiary institutions to provide experiences and means through which students shall gain experiences that will influence their physical, social, emotional growth in desirable ways. However, in order to provide such experiences and means in the study of Business Education, it is pertinent to know that it is better achieved if the business teacher is ICT competent enough to handle and achieve the objectives of Business Education which includes amongst others development of personal skills such as word processing skill, computer fundamental skills and internet. Thus, a business teacher who has acquired the basic ICT competencies required in teaching and learning of Business Education subjects especially skill subjects like office Technology and Management qualifies himself for either of two careers- one in business and the other in teaching profession since the experience gained in either career usually strengthens his qualification for both careers. Information and communication technology is a term used in describing the use of technologies like computers, internets, mobile phones and other communication networks. 
It includes all the technologies that help in disseminating and using information by individuals and institutions. National Board for Technical Education (NBTE) (2004) identified some of the competencies expected of Business Education teachers to include competencies in - word processing, spreadsheet, power point presentation, data base management system among others. Each of these areas of competencies consists of a body of knowledge, skills and abilities which the teacher must possess. (Okoro, 2013). He further explained that for a teacher to teach the use of computer, that the teacher must be computer literate and should have adequate knowledge in computer fundamentals like micro soft words, how to create files, use files, use input device to enter and edit text, manipulate information, preview, print and save a document etc. With power point, a Business Education lecturer can create educational presentation that can add variety and vitality to his teaching. Database on the other hand is an organized collection of data that can produce efficient retrieval when necessary while spreadsheet is a group name for software that is used for financial management and calculation. They are used in a wide range of business situation such as, forecasting, cash flow analysis, budgeting, financial statement preparation, scenario analysis etc. The knowledge in these computer fundamental packages will enable teaching and learning in Business Education to be more effective as it will equip the students with what they will expect in the labour world as well as expose them in being self-reliant and good entrepreneurs in future.

However, it is pertinent to know that some Business Education lecturers in Colleges of Education seem to lack the required ICT skills to cope with the demands of modern office technology and for effective teaching of ICT related courses in the department of Business Education. Often times it seems that these lack of ICT requirement by Business Educators in Colleges of Education could be a gender factor since experience has shown that ICT programmes are mainly handled by male lecturers even though this assertion could be based on personal opinion. Therefore, it is very necessary to examine the ICT competencies required by Business Education lecturers as well as determine the extent in which these ICT competencies are acquired by lecturers in the Colleges of Education in South East Zone of Nigeria hence focus the study.

The main objective of the study is to determine the basic competencies required by Business Education lecturers for effective implementation of Business Education programme. The specific objectives of the study include:

1. To determine the word processing competencies required by Business Education teachers.

2. To ascertain the internet competencies required by business educators.

3. To determine the data base competencies required by business educators.

4. To determine the power point competencies required by business educators

5. To determine the spreadsheet competencies required by business educators.

To address the objectives of this study, the following research questions are posited:

- What are the Microsoft word competencies required by business educators?

- What are the internet competencies required by business educators?

- What are the data base competencies required by business educators?

- What are the power point competencies required by business educators?

- What are the spreadsheet competencies required by business educators?

For the purpose of this study, the following hypotheses are formulated and were tested at 0.05 level of significance.

Ho: There is no significant difference between the mean rating of male and female lecturers on the word processing competencies required by Business Education lecturers in Colleges of Education.

$\mathrm{H}_{1}$ : There is no significant difference between the mean rating of federal and State lecturers on the internet competencies required by Business Education lecturers in Colleges of Education.

$\mathrm{H}_{2}$ : There is no significant difference between the mean ratings of lecturers based on length of service on data base on competencies required by Business Education lecturers in Colleges of Education.

$\mathrm{H}_{3}$ : There is no significant difference between the mean rating of male and female lecturers on power point competencies required by Business Education teachers in Colleges of Education.

$\mathrm{H}_{4}$ : There is no significant difference between the mean ratings of lecturers based on length of service on spreadsheet competencies required by Business Education teachers in Colleges of Education.

This research is significant in that it will help to promote the academic standard of the students in order to achieve a better academic performance in ICT subjects of Business Education. The result of this study will help the ICT lecturers to envisage how best to adapt ICT in terms of teaching method, educational upgrading, human resources development and better academic performance of students in higher institutions in Nigeria. The study will help enlighten the government on various areas of ICT which are required by business educators thereby by enabling them to mobilize an in service training for business educators. 


\section{Methodology}

The study adopted the descriptive survey research design. Descriptive survey research is used for the discovery of meaning in the data collected so that facts and events can be understood, interpreted and explained. The present study fits into the above description as it only sought the opinion of respondents on the ICT skills possessed by Business Education lecturers in the South East of Nigeria. The survey instruments were shared to 65 lecturers in five higher education institutes in south east Nigeria, however, due to unavailability of the all the respondents, the collected survey instruments were 53 questionnaires.

\section{Population of the Study}

The population of this study is made up of all lecturers in Business Education department in the selected Colleges of Education in the South East of Nigeria. The institutions, the owner of the institutions and numbers of lecturers are listed below as follows:

\begin{tabular}{|l|l|l|l|}
\hline S/N & Institutions & Ownership & Lecturers \\
\hline 1. & Federal College of Education Umunze. & Federal & 23 \\
\hline 2. & $\begin{array}{l}\text { Nwafor-Ori-uzor College of Education, } \\
\text { Nsugbe. }\end{array}$ & State & 12 \\
\hline 3. & Ebonyi state College of Education, Ikwo & State & 14 \\
\hline 4. & $\begin{array}{l}\text { Enugu state College of Education } \\
\text { technical Enugu }\end{array}$ & State & 13 \\
\hline 5. & Federal College of Education Eha-Amufu & Federal & 13 \\
\hline & Total & & 65 \\
\hline
\end{tabular}

\section{Sample of the Study}

\begin{tabular}{|l|l|l|l|}
\hline S/N & Institutions & Ownership & Lecturers \\
\hline 1. & Federal College of Education Umunze. & Federal & 12 \\
\hline 2. & $\begin{array}{l}\text { Nwafor-Ori-uzor College of Education, } \\
\text { Nsugbe. }\end{array}$ & State & 09 \\
\hline 3. & Ebonyi state College of Education, Ikwo & State & 11 \\
\hline 4. & $\begin{array}{l}\text { Enugu state College of Education } \\
\text { technical Enugu }\end{array}$ & State & 10 \\
\hline 5. & Federal College of Education Eha-Amufu & Federal & 11 \\
\hline 6. & Total & & 53 \\
\hline
\end{tabular}

The above table shows the sample of the study which was derived from the evaluation of the instrument used for the study.

\section{Instrumentation}

The instrument for data is a structured questionnaire developed by the researcher. The questionnaire is divided into two sections. Section A is prepared to obtain background information of the respondents and comprises three (3) items. Section B contains items grouped into 5 (five) headings in line with the specific purposes of the study. The items are structured on a 4 point rating scale of Very Highly Required (VHR), Highly Required (HR), Moderately Required (MR) and Not Required (NR).The number of questionnaire items derived from each of the five (5) categories of the ICT software under study is shown below:

\begin{tabular}{|l|l|l|}
\hline Groups & \multicolumn{1}{|c|}{ Headings } & No of Items \\
\hline A & ICT competencies in MS-Word sub-skills & 10 \\
\hline B & ICT competencies in Internet services & 10 \\
\hline C & ICT competencies in spreadsheet sub-skills. & 10 \\
\hline D & ICT competencies in power point sub-skills & 10 \\
\hline F & ICT competencies 25in Data base sub-skills. & 10 \\
\hline & Total & 50 \\
\hline
\end{tabular}


Table One: Mean Response on Microsoft Word competencies required by Business Education lecturers in South-East Colleges of Education

\begin{tabular}{|c|c|c|c|c|c|c|c|c|}
\hline $\mathrm{S} / \mathrm{N}$ & Microsoft Word competencies & VHR & HR & MR & NR & Mean & Std & Decision \\
\hline & Ability to start Microsoft Word & 36 & 12 & 4 & 1 & 3.57 & .72 & HR \\
\hline & Ability to use Menu options & 29 & 20 & 3 & 1 & 3.45 & .70 & HR \\
\hline & Ability to create a well formatted document & 29 & 13 & 10 & 1 & 3.32 & .85 & $\mathrm{HR}$ \\
\hline & Ability to save a document & 39 & 9 & 2 & 3 & 3.38 & .82 & HR \\
\hline & Ability to open an existing document & 32 & 15 & 5 & 1 & 3.47 & .75 & HR \\
\hline & Ability to use the tool bar & 28 & 15 & 9 & 1 & 3.32 & .83 & HR \\
\hline & Ability to open an existing word document & 31 & 17 & 4 & 1 & 3.47 & .72 & HR \\
\hline & Ability to print out document & 35 & 10 & 6 & 2 & 3.47 & .85 & HR \\
\hline & Ability to undo and redo text & 24 & 23 & 5 & 1 & 3.32 & .73 & HR \\
\hline & Ability to edit document & 26 & 21 & 5 & 1 & 3.36 & .74 & HR \\
\hline
\end{tabular}

The result of the data analysis of research question 1 as shown in table 1 reveals that business education lecturers require Microsoft Word competencies. This assertion is true since it has a grand mean of 3.43 which is within the range of 2.50 and above which implies that the Business Education lecturers highly require Microsoft Word competency. This finding indicates that Maduabuchi (2008) was right when he posited that many teachers had shallow depth of computer skills in which word processing is inclusive. The respondents also revealed that ability to save document is the most important aspect in the knowledge of Microsoft word while there is none with least importance in the list of items.

Table Two: Mean response on internet competencies required by Business Education lecturers in South East Colleges of Education

\begin{tabular}{|c|c|c|c|c|c|c|c|c|}
\hline $\mathrm{S} / \mathrm{N}$ & Internet Word Competencies & VHR & HR & MR & NR & Mean & Std & Decision \\
\hline & Ability to get connected to the internet & 28 & 20 & 4 & 1 & 3.42 & .72 & HR \\
\hline & Ability to locate a search engine & 26 & 18 & 8 & 1 & 3.30 & .80 & HR \\
\hline & Ability to use the search engine & 25 & 15 & 12 & 1 & 2.21 & .86 & HR \\
\hline & Ability to use an e-mail & 29 & 13 & 2 & 1 & 3.32 & .82 & HR \\
\hline & Ability to locate a website & 25 & 17 & 7 & 4 & 3.19 & .75 & HR \\
\hline & Ability to insert email link on web pages & 16 & 17 & 14 & 6 & 2.81 & .83 & HR \\
\hline & Ability to upgrade an existing service & 16 & 20 & 14 & 3 & 2.92 & .72 & HR \\
\hline & $\begin{array}{l}\text { Ability to edit text in different division on } \\
\text { web pages }\end{array}$ & 15 & 17 & 17 & 4 & 2.81 & .85 & HR \\
\hline & Ability to $\log$ in and out from the internet & 28 & 20 & 4 & 1 & 3.41 & .73 & HR \\
\hline & $\begin{array}{l}\text { Ability to publish web pages to local and } \\
\text { public search engines }\end{array}$ & 19 & 20 & 11 & 3 & 3.03 & .74 & HR \\
\hline
\end{tabular}

The result of the data analysis of research question 2 as shown in table 2 reveals that Business Education lecturers require Internet competencies. This assertion is true since it has a grand mean of 3.41 which is within the range of 2.50 and above which implies that the Business Education lecturers highly require internet competency. This finding indicates that Kingdom e-government policy (2001) stated that emphasis should shift from manual to use of electronic media in government programme. The document explained that this shift can be possible through staff acquisition of skills in relevant area including internet competency. The respondents also revealed that ability to get connected to the internet is the most important aspect in the knowledge of internet while ability to insert an email link on web pages and ability to edit text in different internet competencies. Thus, Agomuo (2014) posited that the main benefit of email is the close to instantaneous delivery of messages. 
Table Three: Mean response on Database competencies required by business education lecturers in selected colleges of education in the South-East.

\begin{tabular}{|c|c|c|c|c|c|c|c|c|}
\hline $\mathrm{S} / \mathrm{N}$ & Database Competencies & VHR & HR & MR & NR & Mean & Std & Decision \\
\hline & Ability to add records from database & 18 & 27 & 7 & 1 & 3.17 & .73 & HR \\
\hline & Ability to generate reports from database & 13 & 23 & 15 & 2 & 2.89 & .82 & HR \\
\hline & $\begin{array}{l}\text { Ability to link information from different } \\
\text { environment }\end{array}$ & 15 & 23 & 12 & 3 & 2.94 & .86 & HR \\
\hline & $\begin{array}{l}\text { Ability to share information among } \\
\text { different work stations }\end{array}$ & 18 & 21 & 11 & 3 & 3.01 & .89 & HR \\
\hline & $\begin{array}{l}\text { Ability to use Access objects e.g. tables, } \\
\text { forms, query, etc }\end{array}$ & 10 & 23 & 7 & 3 & 3.13 & .86 & HR \\
\hline & $\begin{array}{l}\text { Ability to Access objects e.g. tables, } \\
\text { forms, query etc. }\end{array}$ & 15 & 23 & 13 & 2 & 2.96 & .83 & HR \\
\hline & $\begin{array}{l}\text { Ability to use tags for various types of } \\
\text { objects }\end{array}$ & 8 & 23 & 20 & 2 & 2.70 & .77 & HR \\
\hline & $\begin{array}{l}\text { Ability to plan a database before creating } \\
\text { it. }\end{array}$ & 14 & 25 & 11 & 3 & 2.94 & .84 & HR \\
\hline & Ability to design tables & 17 & 15 & 18 & 3 & 2.87 & .94 & HR \\
\hline & Ability to design fields using data types & 16 & 27 & 13 & 3 & 3.06 & .82 & HR \\
\hline
\end{tabular}

The result of the data analysis of research question 3 as shown in table 3 reveals that Business Education lecturers require Database competencies. This assertion is true since it has a grand mean of 2.97 which is within the range of 2.50 and above which implies that the Business Education lecturers highly require Database competency. This finding is in agreement with the observations of Ohakwe and Njoku (2010) that Business Education lecturers require Database competencies for effective utilization of technologies in their classrooms and other presentations. Therefore it is necessary for Business Education lecturers to have the knowledge of Database. The finding also revealed that ability to add records from database is the most important aspect in the knowledge of Database while ability to use tags for various types of objects is seen as the least important knowledge in Database competency. The finding of this study is in consonance with that of Garba (2012) who found out that data base is highly required by business educators. He explained that proficiency in database is very important for performing office activities.

Table 4: Mean response on PowerPoint competencies required by business education lecturers in selected colleges of education in the South-East

\begin{tabular}{|lllllllll}
\hline S/N & Internet Word Competencies & VHR & HR & MR & NR & Mean & Std & Decision
\end{tabular}

\begin{tabular}{|c|c|c|c|c|c|c|}
\hline $\begin{array}{l}\text { Ability to open a PowerPoint work } \\
\text { environment }\end{array}$ & 14 & 28 & 9 & 2 & 3.02 & .78 \\
\hline $\begin{array}{l}\text { Ability to create slides using different } \\
\text { layouts }\end{array}$ & 28 & 21 & 3 & 1 & 3.43 & .69 \\
\hline Ability to assign tables to a slide & 13 & 32 & 7 & 1 & 3.08 & .68 \\
\hline $\begin{array}{l}\text { Ability to change font sizes of text in a } \\
\text { slide }\end{array}$ & 12 & 24 & 12 & 5 & 3.81 & .90 \\
\hline Ability to set up a presentation & 21 & 24 & 7 & 1 & 3.23 & .75 \\
\hline Ability to create object in a presentation & 12 & 25 & 13 & 3 & 2.87 & .83 \\
\hline Ability to print out slides & 12 & 31 & 6 & 4 & 2.96 & .81 \\
\hline Ability to store slide presentation & 12 & 31 & 7 & 3 & 2.98 & .77 \\
\hline $\begin{array}{l}\text { Ability to make a presentation using slides } \\
\text { and projectors }\end{array}$ & 14 & 30 & 7 & 2 & 3.06 & .74 \\
\hline $\begin{array}{l}\text { Ability to edit a presentation using a } \\
\text { template }\end{array}$ & 14 & 26 & 9 & 4 & 2.94 & .86 \\
\hline
\end{tabular}

The result of the data analysis of research question 4 as shown in table 4 reveals that Business Education lecturers require PowerPoint competencies. This assertion is true since it has a grand mean of 3.11 which is within the range of 2.50 and above which implies that the Business Education lecturers highly require PowerPoint competency. This 
finding is in agreement with the observations of Onuoha in Okolocha and Nwadiani (2014) that Business Education lecturers require PowerPoint competencies for effective utilization of technologies in their classrooms and other presentations. Therefore it is necessary for Business Education lecturers to have the knowledge of PowerPoint. The respondents also revealed that ability to change font sizes of text in a slide is the most important aspect in the knowledge of PowerPoint while ability to create object in a presentation is seen as the least important knowledge in PowerPoint competency.

Table 5: Mean response on Spreadsheet competencies required by business education lecturers in selected colleges of education in the South-East

\begin{tabular}{|c|c|c|c|c|c|c|c|c|}
\hline $\mathrm{S} / \mathrm{N}$ & Spread Sheet Competencies & VHR & HR & MR & NR & Mean & Std & Decision \\
\hline & $\begin{array}{l}\text { Ability to open a Spread Sheet application } \\
\text { software }\end{array}$ & 25 & 23 & 4 & 1 & 2.98 & .80 & HR \\
\hline & Ability to plan a spread sheet & 19 & 28 & 6 & & 3.25 & 65 & HR \\
\hline & Ability to use columns and rows & 18 & 26 & 8 & 1 & 3.15 & .74 & HR \\
\hline & $\begin{array}{l}\text { Ability to move from cell to cell in Ms- } \\
\text { Excel }\end{array}$ & 16 & 28 & 7 & 2 & 3.09 & .77 & HR \\
\hline & Ability to change Spread sheet look & 15 & 21 & 11 & 6 & 2.85 & .97 & HR \\
\hline & Ability to manipulate data & 17 & 21 & 10 & 6 & 2.94 & .95 & HR \\
\hline & Ability to produce basic spread sheet & 10 & 36 & 6 & 1 & 3.04 & 62 & HR \\
\hline & Ability to create an arithmetic formula & 15 & 23 & 12 & 3 & 2.94 & 66 & HR \\
\hline & Ability to use common excel functions & 25 & 23 & 12 & 3 & 2.94 & .86 & HR \\
\hline & Ability to fill formulae automatically & 14 & 24 & 13 & 2 & 2.94 & .82 & HR \\
\hline
\end{tabular}

The result of the data analysis of research question 5 as shown in table 5 reveals that Business Education lecturers require spreadsheet competencies. This assertion is true since it has a grand mean of 3.02 which is within the range of 2.50 and above which implies that the Business Education lecturers highly require spreadsheet competencies. This finding is in agreement with the observations of Akarahu and lle (2014) when they revealed that business education teachers require spreadsheet competencies for generation of students' results using Excel. Therefore it is necessary for Business Education lecturers to have the knowledge of Spreadsheet; this will enable the teaching of accounting to be easier and more understandable. This assertion is in union with Kingdom e-government policy (2001) that stated that emphasis should be made more on use of electronic technologies in the office rather than manual. Thus, the study also revealed that ability to use columns and rows are the most important aspect in the knowledge of spreadsheet while ability to change spreadsheet look is seen as the least important knowledge in learning of spreadsheet competencies.

\section{Hypotheses Analysis}

Table 6: t-test of Independent on the mean rating of male and female lecturers on the word processing competencies required by Business Education lecturers

\begin{tabular}{|c|c|c|c|c|c|c|c|c|c|}
\hline $\mathrm{S} / \mathrm{N}$ & Microsoft Word Competences & Gender & $\mathrm{N}$ & Mean & SD & $\mathrm{DF}$ & t-cal & t-crit & Decision \\
\hline \multirow[t]{2}{*}{1} & \multirow{2}{*}{ Ability to start Microsoft word } & Male & 27 & 3.52 & 0.80 & 51 & -0.49 & 2.00 & Accept \\
\hline & & Female & 26 & 3.62 & 0.64 & & & & \\
\hline \multirow[t]{2}{*}{2} & \multirow{2}{*}{ Ability to use menu options } & Male & 27 & 3.44 & 0.75 & 51 & -0.09 & 2.00 & Accept \\
\hline & & Female & 26 & 3.46 & 0.65 & & & & \\
\hline \multirow[t]{2}{*}{3} & \multirow{2}{*}{ Ability to create a well formatted document } & Male & 27 & 3.30 & 0.91 & 51 & -0.21 & 2.00 & Accept \\
\hline & & Female & 26 & 3.35 & 0.80 & & & & \\
\hline \multirow[t]{2}{*}{4} & \multirow{2}{*}{ Ability to save a document } & Male & 27 & 3.56 & 0.89 & 51 & -0.26 & 2.00 & Accept \\
\hline & & Female & 26 & 3.62 & 0.75 & & & & \\
\hline \multirow[t]{2}{*}{5} & \multirow{2}{*}{ Ability to open an existing document } & Male & 27 & 3.44 & 0.80 & 51 & -0.27 & 2.00 & Accept \\
\hline & & Female & 26 & 3.50 & 0.71 & & & & \\
\hline \multirow[t]{2}{*}{6} & \multirow{2}{*}{ Ability to use the tool bar } & Male & 27 & 3.30 & 0.87 & 51 & -0.22 & 2.00 & Accept \\
\hline & & Female & 26 & 3.35 & 0.80 & & & & \\
\hline \multirow[t]{2}{*}{7} & \multirow{2}{*}{ Ability to open an existing word document } & Male & 27 & 3.44 & 0.80 & 51 & -0.28 & 2.00 & Accept \\
\hline & & Female & 26 & 3.50 & 0.65 & & & & \\
\hline \multirow[t]{2}{*}{8} & \multirow{2}{*}{ Ability to print out a document } & Male & 27 & 3.48 & 0.85 & 51 & 0.09 & 2.00 & Accept \\
\hline & & Female & 26 & 3.46 & 0.86 & & & & \\
\hline \multirow[t]{2}{*}{9} & \multirow{2}{*}{ Ability to undo and redo text } & Male & 27 & 3.33 & 0.68 & 51 & 0.13 & 2.00 & Accept \\
\hline & & Female & 26 & 3.31 & 0.79 & & & & \\
\hline \multirow[t]{2}{*}{10} & \multirow{2}{*}{ Ability to edit document } & Male & 27 & 3.33 & 0.78 & 51 & -0.25 & 2.00 & Accept \\
\hline & & Female & 26 & 3.39 & 0.70 & & & & \\
\hline
\end{tabular}


The data on table 6 reveals that all the items one to ten $(1-10)$ were accepted. As a result, the null hypothesis was accepted that there is no significant difference between the mean rating of male and female lecturers on the word processing competencies required by Business Education lecturers in Colleges of Education.

Table 7: t-test of Independent on the mean rating of federal and State lecturers on the internet competencies required by Business Education lecturers

\begin{tabular}{|c|c|c|c|c|c|c|c|c|c|}
\hline $\mathrm{S} / \mathrm{N}$ & Internet Competencies & Ownership & $\mathrm{N}$ & Mean & $\mathrm{SD}$ & DF & t-cal & t-crit & Decision \\
\hline \multirow[t]{2}{*}{$\overline{11}$} & \multirow{2}{*}{ Ability to get connected to the internet } & State & 27 & 3.37 & 0.79 & 51 & -0.46 & 2.00 & Accept \\
\hline & & Federal & 26 & 3.46 & 0.65 & & & & \\
\hline \multirow[t]{2}{*}{12} & \multirow{2}{*}{ Ability to locate a search engine } & State & 27 & 3.26 & 0.86 & 51 & -0.39 & 2.00 & Accept \\
\hline & & Federal & 26 & 3.35 & 0.75 & & & & \\
\hline \multirow[t]{2}{*}{13} & \multirow{2}{*}{ Ability to use the search engine } & State & 27 & 3.19 & 0.92 & 51 & -0.19 & 2.00 & Accept \\
\hline & & Federal & 26 & 3.23 & 0.82 & & & & \\
\hline \multirow[t]{2}{*}{14} & \multirow{2}{*}{ Ability to use an e-mail } & State & 27 & 3.30 & 0.91 & 51 & -0.21 & 2.00 & Accept \\
\hline & & Federal & 26 & 3.35 & 0.80 & & & & \\
\hline \multirow[t]{2}{*}{15} & \multirow{2}{*}{ Ability to locate a web site } & State & 27 & 3.19 & 0.96 & 51 & -0.027 & 2.00 & Accept \\
\hline & & Federal & 26 & 3.19 & 0.94 & & & & \\
\hline \multirow[t]{2}{*}{16} & \multirow{2}{*}{$\begin{array}{l}\text { Ability to insert an e-mail links on } \\
\text { Webpages }\end{array}$} & State & 27 & 2.81 & 1.00 & 51 & 0.03 & 2.00 & Accept \\
\hline & & Federal & 26 & 2.81 & 1.02 & & & & \\
\hline \multirow[t]{2}{*}{17} & \multirow{2}{*}{ Ability to upgrade an existing services } & State & 27 & 2.89 & 0.93 & 51 & -0.29 & 2.00 & Accept \\
\hline & & Federal & 26 & 2.96 & 0.87 & & & & \\
\hline \multirow[t]{2}{*}{18} & \multicolumn{2}{|c|}{ Ability to edit text in different divisionState } & 27 & 2.82 & 0.96 & 51 & 0.03 & 2.00 & Accept \\
\hline & on Webpages & Federal & 26 & 2.81 & 0.94 & & & & \\
\hline \multirow[t]{2}{*}{19} & \multirow{2}{*}{$\begin{array}{l}\text { Ability to log in and out from the } \\
\text { internet }\end{array}$} & State & 27 & 3.37 & 0.79 & 51 & -0.46 & 2.00 & Accept \\
\hline & & Federal & 26 & 3.46 & 0.65 & & & & \\
\hline \multirow[t]{2}{*}{20} & \multirow{2}{*}{$\begin{array}{l}\text { Ability to publish Webpages to local } \\
\text { and public search engines }\end{array}$} & State & 27 & 3.04 & 0.94 & 51 & -0.01 & 2.00 & Accept \\
\hline & & Federal & 26 & 3.04 & 0.87 & & & & \\
\hline
\end{tabular}

Data on table 7 indicates that the t-cal values in items eleven to twenty $(11-20)$ is less than the t-critical values. Consequently, the null hypothesis was accepted that there is no significant difference between the mean rating of federal and State lecturers on the internet competencies required by Business Education lecturers in Colleges of Education

Table 8: t-test of Independent on the mean rating of lecturers based on length of service on data base on competencies required by Business Education lecturers

\begin{tabular}{|c|c|c|c|c|c|c|c|c|c|}
\hline $\mathrm{S} / \mathrm{N}$ & Database competencies & Experience & $\mathrm{N}$ & Mean & SD & $\mathrm{DF}$ & $\mathrm{t}$-cal & t-crit & Decision \\
\hline \multirow[t]{2}{*}{$\overline{21}$} & \multirow{2}{*}{$\begin{array}{l}\text { Ability to add records from } \\
\text { database }\end{array}$} & Low experience & 27 & 3.15 & 0.77 & \multirow[t]{2}{*}{51} & \multirow[t]{2}{*}{-0.22} & \multirow[t]{2}{*}{2.00} & \multirow[t]{2}{*}{ Accept } \\
\hline & & High experience & 26 & 3.19 & 0.69 & & & & \\
\hline \multirow[t]{2}{*}{22} & Ability to generate reports & Low experience & 27 & 2.89 & 0.85 & \multirow[t]{2}{*}{51} & \multirow[t]{2}{*}{0.02} & \multirow[t]{2}{*}{2.00} & \multirow[t]{2}{*}{ Accept } \\
\hline & from database & High experience & 26 & 2.89 & 0.82 & & & & \\
\hline \multirow[t]{2}{*}{23} & Ability to link information & Low experience & 27 & 2.93 & 0.92 & \multirow[t]{2}{*}{51} & \multirow[t]{2}{*}{-0.15} & \multirow[t]{2}{*}{2.00} & \multirow[t]{2}{*}{ Accept } \\
\hline & from different environment & High experience & 26 & 2.96 & 0.82 & & & & \\
\hline \multirow[t]{2}{*}{24} & \multirow{2}{*}{$\begin{array}{l}\text { Ability to share information } \\
\text { among different } \\
\text { workstations }\end{array}$} & Low experience & 27 & 3.00 & 0.92 & \multirow[t]{2}{*}{51} & \multirow[t]{2}{*}{-0.16} & \multirow[t]{2}{*}{2.00} & \multirow[t]{2}{*}{ Accept } \\
\hline & & High experience & 26 & 3.04 & 0.87 & & & & \\
\hline \multirow[t]{2}{*}{25} & \multirow{2}{*}{$\begin{array}{l}\text { Ability to use Access } \\
\text { environment e.g. Title bar, } \\
\text { menu bar, etc. }\end{array}$} & Low experience & 27 & 3.11 & 0.89 & \multirow[t]{2}{*}{51} & \multirow[t]{2}{*}{-0.18} & \multirow[t]{2}{*}{2.00} & \multirow[t]{2}{*}{ Accept } \\
\hline & & High experience & 26 & 3.15 & 0.83 & & & & \\
\hline \multirow[t]{2}{*}{26} & Ability to Access objects & Low experience & 27 & 2.96 & 0.85 & \multirow[t]{2}{*}{51} & \multirow[t]{2}{*}{0.01} & \multirow[t]{2}{*}{2.00} & \multirow[t]{2}{*}{ Accept } \\
\hline & e.g. tables, forms, query, etc. & High experience & 26 & 2.96 & 0.82 & & & & \\
\hline \multirow[t]{2}{*}{27} & Ability to use tags for & Low experience & 27 & 2.70 & 0.78 & 51 & 0.05 & 2.00 & Accept \\
\hline & various types of objects & High experience & 26 & 2.69 & 0.79 & & & & \\
\hline 28 & Ability to plan a database & Low experience & 27 & 2.93 & 0.87 & 51 & -0.15 & 2.00 & Accept \\
\hline & before creating it & High experience & 26 & 2.96 & 0.82 & & & & \\
\hline 29 & Ability to desion tables & Low experience & 27 & 2.85 & 0.99 & 51 & -0.13 & 2.00 & Accept \\
\hline & Aomity to uesigin tavies & High experience & 26 & 2.88 & 0.91 & & & & \\
\hline 30 & Ability to design fields using & Low experience & 27 & 3.04 & 0.85 & 51 & -0.18 & 2.00 & Accept \\
\hline & data types & High experience & 26 & 3.08 & 0.80 & & & & \\
\hline
\end{tabular}

The data on table 8 shows that the t-values of all the items, twenty one to thirty $(21-30)$ were accepted. Thus, the null hypothesis was accepted that there is no significant difference between the mean ratings of lecturers based on length of service on data base on competencies required by Business Education lecturers in Colleges of Education. 
Table 9: t-test of Independent on the mean rating of male and female lecturers on power point competencies required by Business Education teachers

\begin{tabular}{|c|c|c|c|c|c|c|c|c|c|}
\hline $\mathrm{S} / \mathrm{N}$ & Power Point Competencies & Gender & $\mathrm{N}$ & Mean & SD & $\mathrm{DF}$ & $\mathrm{t}$-cal & t-crit & Decision \\
\hline \multirow[t]{2}{*}{$\overline{31}$} & \multirow{2}{*}{ Ability to open a power point work environment } & Male & 27 & 3.00 & 0.78 & 51 & -0.18 & 2.00 & Accept \\
\hline & & Female & 26 & 3.04 & 0.77 & & & & \\
\hline \multirow[t]{2}{*}{32} & \multirow{2}{*}{ Ability to create slides using different layouts } & Male & 27 & 3.40 & 0.75 & 51 & -0.28 & 2.00 & Accept \\
\hline & & Female & 26 & 3.46 & 0.65 & & & & \\
\hline \multirow[t]{2}{*}{33} & \multirow{2}{*}{ Ability to assign titles to a slide } & Male & 27 & 3.07 & 0.73 & 51 & -0.02 & 2.00 & Accept \\
\hline & & Female & 26 & 3.08 & 0.63 & & & & \\
\hline \multirow[t]{2}{*}{34} & \multirow{2}{*}{ Ability to change font sizes of text in a slide } & Male & 27 & 2.78 & 0.93 & 51 & -0.27 & 2.00 & Accept \\
\hline & & Female & 26 & 2.85 & 0.88 & & & & \\
\hline \multirow[t]{2}{*}{35} & \multirow{2}{*}{ Ability to set up a presentation } & Male & 27 & 3.22 & 0.80 & 51 & -0.04 & 2.00 & Accept \\
\hline & & Female & 26 & 3.23 & 0.71 & & & & \\
\hline \multirow[t]{2}{*}{36} & \multirow{2}{*}{ Ability to create object in a presentation } & Male & 27 & 2.85 & 0.86 & 51 & -0.14 & 2.00 & Accept \\
\hline & & Female & 26 & 2.88 & 0.82 & & & & \\
\hline \multirow[t]{2}{*}{37} & \multirow{2}{*}{ Ability to print out slides } & Male & 27 & 2.96 & 0.81 & 51 & 0.01 & 2.00 & Accept \\
\hline & & Female & 26 & 2.96 & 0.82 & & & & \\
\hline \multirow[t]{2}{*}{38} & \multirow{2}{*}{ Ability to store slide presentation } & Male & 27 & 2.96 & 0.81 & 51 & -0.17 & 2.00 & Accept \\
\hline & & Female & 26 & 3.00 & 0.75 & & & & \\
\hline \multirow[t]{2}{*}{39} & \multirow{2}{*}{$\begin{array}{l}\text { Ability to make a presentation using slides and } \\
\text { projectors }\end{array}$} & Male & 27 & 3.04 & 0.76 & 51 & -0.19 & 2.00 & Accept \\
\hline & & Female & 26 & 3.08 & 0.74 & & & & \\
\hline \multirow[t]{2}{*}{40} & \multirow{2}{*}{ Ability to edit a presentation using a template } & Male & 27 & 2.93 & 0.87 & 51 & -0.15 & 2.00 & Accept \\
\hline & & Female & 26 & 2.96 & 0.87 & & & & \\
\hline
\end{tabular}

The data on table 9 indicates that the $\mathrm{t}$-cal values in items thirty one to forty (31-40) were less than the t-critical values. Hence, the null hypothesis was accepted that there is no significant difference between the mean rating of male and female lecturers on power point competencies required by Business Education teachers in Colleges of Education.

Table 10: T-test of Independent on the mean rating of lecturers based on length of service on spreadsheet competencies required by Business Education teachers

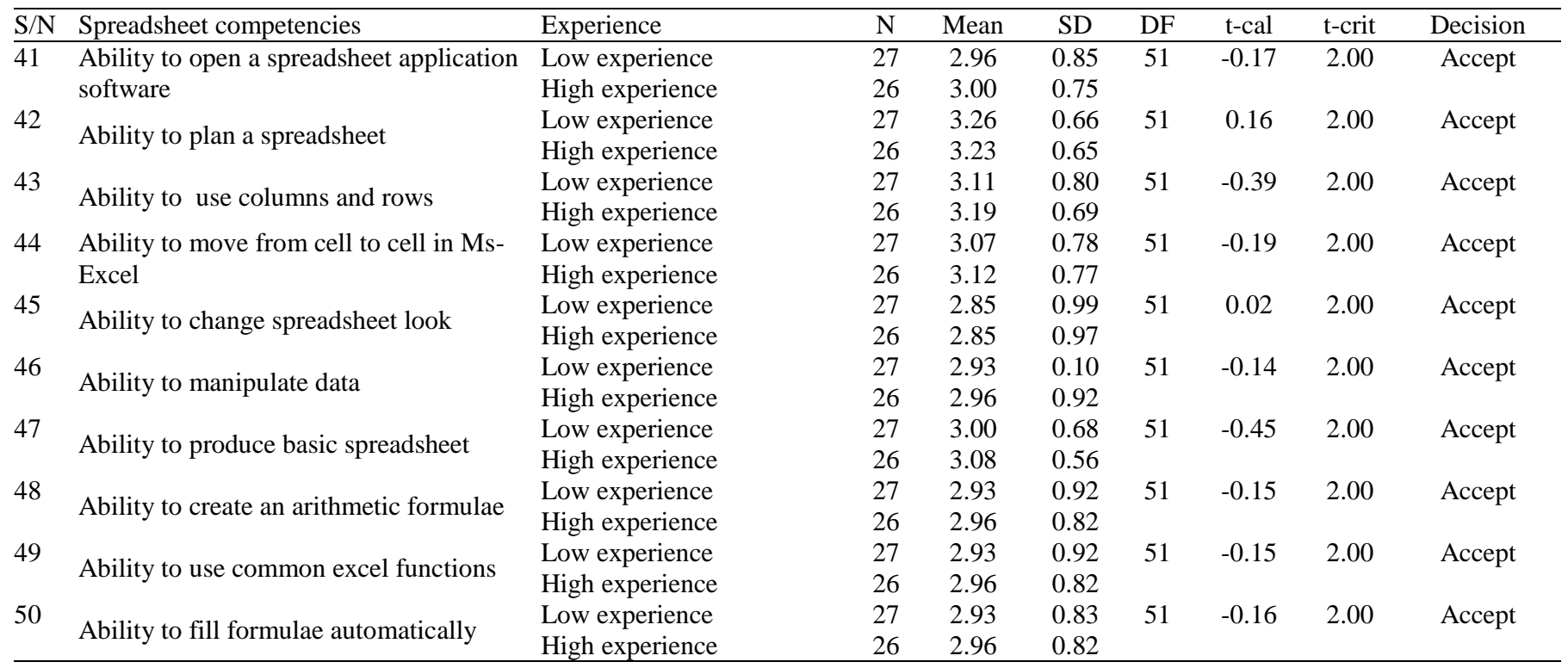

Data on table 10 shows that the t-cal values in items forty one to fifty $(41-50)$ indicated there is no significant difference between the mean rating of lecturers based on length of service on spreadsheet competencies required by Business Education teachers in Colleges of Education.

\section{Conclusion}

The study showed that the ICT competencies required by Business Education lecturers are Microsoft word, internet, PowerPoint, Spreadsheet and Database amongst others. The knowledge of these ICT competencies is highly required for effective teaching and learning of Business Education as a Subject in Colleges of Education. Therefore there is need for every Business Education Lecturer to acquire the knowledge of these ICT competencies. This will enhance the interest rate in the study of Business Education and as well the aspiration in teaching and learning will be encouraged. 


\section{Recommendations}

The following recommendations were made based on the findings and conclusion of the study.

1 Lecturers should be encouraged to go for in service training to enable self-paced learning through e-learning as well as by fostering a live contact between teachers and learners through e-mail, chalk session, web based learning including the use of internet.

2. The school management through TETFUND should enable all Business Education lecturers acquire a good personal computer (Laptops). This will enable them acquire more teacher pedagogical practices and reasoning. This assertion is true because if practices are inadequate or inappropriate, then teachers will not be sufficiently prepared and confident enough to make full use of ICT in and out of the classroom.

\section{References}

Agomuo, E.E(2014).Modern Office Technology, Issues, Procedures and Practice. Enugu: Debees Printing Services.

Akarahu, C., \& Ile C.M. (2014). Competency improvement needs of teachers of business education in colleges of education on the use of new technology for production of employable graduates. Nigeria journal of Business Education 29(1) 354-364.

Federal Republic of Nigeria.(2004) National Policy on Education. Abuja: NERDC Press.

Garba, A. M. (2012). Self-assessment on office applications proficiency by office technology management students in North-West Nigeria polytechnics. A thesis submitted to the Department of Vocational Education, Faculty of Education NnamdiAzikiwe University, Awka.

Igboke,S.A.(2012).Strategies for reducing management constraints inbusiness teacher education programmes in Nigeria.Ebonyi State University Journal of Education 2(1).

Maduabuchi, I. (2008). A critique of new curriculum in office technology and business management and the relationship between ICT and integration and the standard of teacher education programmes in developing economy. International Education using ICT 2(3) 70-85.

NBTE (2004).Office technology and management curriculum and course specifications. Kaduna: Atman Ltd.

Ohakwe, S.N. (2008). ICT Power-Point presentation sub-skills required by business education reform delivery system.Business Education Journal 6(2) 96-111.

Okolocha, C. C., \&Nwadiani, C. O. (2014). Business studies teachers' preparedness towards the challenges of new technological involutions in teaching in Egor and Oredo local Government Area of Edo State. Nigeria Journal of Business Education 2 (1) 57-68.

Okoro, O.B. (2013).Assessment of ICT competencies possessed by polytechnic OTM lecturers in south-south geopolitical zone of Nigeria. A thesis submitted to the Department of Vocational Education, Faculty of Education, NnamdiAzikiwe University, Awka.

United Kingdom Government.(2001). E-government policy framework for electronic record management. Retrieved on $22^{\text {nd }}$ February 2015 from www.pro.gov.uk/redsmgt 